\title{
TEKNIK REPRESENTASI KEBUTUHAN PENGGUNA MENGGUNAKAN USER PERSONA (STUDI KASUS: RELASI ANTARA PRESENSI DENGAN KEMAMPUAN KOMPETENSI)
}

\author{
Wahyu Andhika*1, Muhammad Iqbal' ${ }^{2}$ Munifah Nur ${ }^{3}$, Rizkhi Dwi Nugroho ${ }^{4}$ \\ 1,2,3,4 Universitas Muhammadiyah Malang \\ Email: ${ }^{1}$ kusuma.wahyu.a@gmail.com, ${ }^{2}$ i.ramadhanm208@gmail.com, ${ }^{3}$ munifahnurf@gmail.com, \\ 4rizkhidwin@gmail.com \\ *Penulis Korespondensi
}

(Naskah masuk: 10 April 2020, diterima untuk diterbitkan: 18 Maret 2021)

\begin{abstract}
Abstrak
Elisitasi kebutuhan dalam proses pengembangan perangkat lunak adalah fase yang sangat penting dalam Software Development Lifecycle. Karena dalam tahap ini ditentukan dengan tepat mengenai apa yang akan dibuat. Sebuah sistem baiknya memenuhi kebutuhan dari pengguna. Oleh karena itu, melibatkan pengguna dalam elisitasi kebutuhan menjadi salah satu fase yang sangat berguna dalam menentukan kualitas persona experience dalam suatu sistem. Keterlibatan pengguna membuat pengembang harus memahami dengan baik apa saja yang akan menjadi kebutuhan pengguna. Pendekatan yang efektif dibutuhkan untuk mengenali pengguna dan merangkum kebutuhannya dengan baik dengan segala keunikan pada setiap individu yang mungkin terjadi. Menggunakan metode persona, penelitian ini akan menyelesaikan permasalahan berupa informasi dari pengguna yang tidak menggambarkan kebutuhan secara lengkap. Metode ini akan membantu menggambarkan seorang pengguna secara mendalam mulai dari kepribadian, kemampuan hingga perilaku pengguna terhadap suatu masalah. Dokumen mengenai pengguna secara detail kemudian disimpulkan agar didapatkan sebuah kebutuhan dasar untuk diimplementasikan menjadi sebuah sistem. Selain menggunakan metode persona dalam meningkatkan elisitasi kebutuhan, penelitian ini juga berfokus pada nilai kualitatif informasi tersebut dengan menambahkan implementasi teori iteratif. Teori ini digunakan untuk meningkatkan akurasi penyelesaian masalah, yang mana pada setiap tahapnya akan menghasilkan informasi yang akan memudahkan pengembang dalam mendesain perangkat lunak yang berorientasi pada pengguna.
\end{abstract}

Kata kunci: elisitasi kebutuhan, user persona, presensi, kompetensi

\section{TECHNIQUES FOR REPRESENTATION USER NEEDS USING PERSONA. (CASE STUDY: RELATIONSHIP BETWEEN ATTEND AND COMPETENCY ABILITY)}

\begin{abstract}
Elicitation of needs in the software development process is a very important phase in the Software Development Lifecycle. Because in this stage it is precisely determined what will be made. A good system meets the needs of personas. Therefore, involving personas in the elicitation of needs is one phase that is very useful in determining the quality of persona experience in a system. User involvement makes the developer must understand well what will be the persona's needs. An effective approach is needed to recognize the persona and summarize his needs well with all the uniqueness in each individual that might occur. By using the persona method, this research will solve problems in the form of information from personas who do not describe the needs in full. This method will help describe a persona in depth ranging from personality, ability to persona behavior towards a problem. The detailed persona document is then concluded in order to obtain a basic requirement to be implemented into a system. In addition to using the persona method in increasing the elicitation of needs, this research also focuses on the qualitative value of the information by adding iterative theory implementation. This theory is used to improve the accuracy of problem solving, which at each stage will produce information that will facilitate developers in designing persona-oriented software.
\end{abstract}

Keywords : requirement elicitation, persona, attend, competence 


\section{PENDAHULUAN}

HCI atau Human Computer Interaction membahas tentang desain evaluasi dan implementasi sistem komputer dengan manusia. Ini melibatkan beberapa orang sebagai kelompok dan teknik ini memastikan bahwa produk perangkat lunak output sesuai untuk standar kegunaan minimum (Acuña, Castro and Juristo, 2012)

Dalam "Software Engineering Body of Knowledge" (SWEBOK) (Estublier, 2000), dijelaskan bahwa proses pengembangan perangkat lunak melibatkan beberapa fase, di antaranya, pengumpulan kebutuhan, analisis, desain, arsitektur, implementasi dan pemeliharaan. Di mana diantara beberapa fase tersebut, fase penggalian kebutuhan menjadi fase yang sangat penting (Mulla, 2012).

Fase penggalian kebutuhan atau rekayasa kebutuhan adalah praktik yang membantu dalam menentukan kebutuhan customer, persona dan stakeholder dalam membangun sistem dan perangkat lunak yang dapat menghasilkan probabilitas tinggi untuk memenuhi kebutuhan tersebut. Hal inilah yang membuat fase rekayasa kebutuhan sangat menuntut perhatian dalam menyusun skenario kebutuhan yang tepat. Karena pengembangan kebutuhan yang dilakukan dengan kesalahan akan menyebabkan kualitas sistem yang buruk, penyelesaian yang terlambat dan ketidakpuasan persona dalam menggunakannya (Wong, Mauricio and Rodriguez, 2017). Dalam fase ini pula, aktifitas yang dilibatkan antara lain pencarian, pendokumentasian dan menelaah kebutuhan, yang mana semuanya telah tercakup dalam proses rekayasa kebutuhan.

Persona adalah teknik yang terbukti bermanfaat untuk elisitasi kebutuhan dalam pengembangan perangkat lunak (Anvari et al., 2015). Metode ini melibatkan banyak pengumpulan informasi mengenai persona yang dikumpulkan dengan teknik elisitasi kebutuhan. Dalam metode ini, pengembang diharuskan untuk mengerti mengenai karakteristik persona dan mendefinisikannya ke dalam deskripsi spesifik (Ferreira et al., 2018).

Penggalian informasi guna memenuhi data persona persona memerlukan banyak waktu untuk kemudian disusun dan dirangkum ke dalam deskripsi persona. Tentu saja tidak hanya satu persona saja yang akan dilibatkan dalam sebuah penelitian penggalian kebutuhan. Sistem yang melibatkan sebuah kelompok atau komunitas tertentu juga akan melibatkan orang-orang dalam komunitas tersebut yang mana akan ada banyak orang yang harus dibuatkan masing-masing personanya. Hal ini dapat menyebabkan penggunaan resource dan waktu secara berlebih yang dinilai tidak efisien.

Untuk itu, penggalian kebutuhan akan dilakukan dengan metode pendekatan persona persona yang dalam pengumpulan informasinya telah disinkronisasikan dengan pemanfaatan teori iterasi yang dikemukakan oleh Jacob Nielsen.
Sehingga nilai kualitatif kebutuhan yang optimal akan didapatkan namun tetap mempertahankan penggunaan resource dengan seefisien mungkin.

Penelitian ini akan menggali kebutuhan melalui pendekatan interaksi manusia dengan komputer dengan pengumpulan persona persona berupa karakteristik dari orang-orang yang berkaitan. Persona akan berupa karakteristik dan tujuan berdasarkan survei dari persona. Data kualitatif dan kuantitatif akan dikumpulkan, dianalisis, dan disintesis yang nantinya akan menjadi latar desain persona. Orisinalitas dari teknik ini adalah lebih endefinisikan komponen psikologis, objektif, motivasi dan kebiasaan daripada demografi atau data sosial. Di mana elemen dari deskripsi yang paling terkait dengan masalah akan berguna untuk mengidentifikasi solusi yang mungkin terjadi pada setiap profil (Blanco, López-Forniés and ZarazagaSoria, 2017).

\section{METODE PENELITIAN}

Dalam penelitian ini, teknik elisitasi kebutuhan yang digunakan adalah dengan pendekatan persona persona dari interaksi manusia dan komputer. Dalam teknik ini, terdapat 10 (sepuluh) tahap aktifitas yang dilaksanakan secara sistematis untuk menggali kebutuhan dengan pendekatan persona persona. State Hypotheses adalah kegiatan yang mendeskripsikan masalah dasar yang ditemukan. Kemudian membuat daftar hipotesis untuk persona, dan melakukan identifikasi serta wawancara dengan calon pengguna (Acuña, Castro and Juristo, 2012). Identify Behavioral Variables melibatkan pengguna akhir dalam elisitasi persyaratan membantu menghasilkan aplikasi dengan pengalaman penggunaan yang positif (Ferreira et al., 2018).

Dengan cara mengumpulkan variabel perilaku dari berbagai aspek, cara yang paling mendekati adalah dengan wawancara. Map Interview Subjects to Behavioral Variables adalah untuk membuat peta subjek wawancara ke variabel perilaku menghasilkan rentang variabel perilaku dan pemetaan subjek wawancara. Produk-produk ini adalah input untuk aktivitas (Castro, Acuña and Juristo, 2008). Setelah mengumpulkan variable dari berbagai aspek, membuat aktifitas baru yaitu membuat rentang nilai. Menyusun (mapping) aspek di rentang tertentu berdasarkan sifatnya. Identify Significant Behavior Patterns kemudian menggelompokkan 6 sampai 12 subjek yang berbeda dan menghasilkan presentase. Untuk mengidentifikasi kelompok-kelompok yang berkepentingan, yaitu, orang-orang yang berinteraksi lebih sering, dan mengelompokkan jaringan sosial yang dibangun pada fase sebelumnya. Kemudian dari presentase tersebut dibuatlah pola tertentu dalam fase Synthesize Characteristics and Relevant Goals. Dengan tujuan mencerminkan kepribadian persona. 
Data yang diperoleh selama pertemuan kemudian dianalisis dan dijabarkan dengan sintesis (Bagriyanik and Karahoca, 2014). Check for Redundancy and Completeness dilakukan untuk menganalisa ulang hasil dari mapping, memastikan keterangan dari subjek, dengan cara mendokumentasikan (ditulis atau direkam). Selama kegiatan ini, analis atau klien perwakilan akan memverifikasi dokumen yang dihasilkan untuk mengidentifikasi keberadaan redundansi atau kelalaian dalam data. Kegiatan ini mencakup persyaratan proses validasi (Santos et al., 2014). Expand the Description of Attributes and Behaviors menjelaskan deskripsi dari persona, dengan membuat narasi singkat dalam hal pekerjaan atau gaya hidup mereka. Struktur psikologis yang dipilih dalam persona adalah: Identitas, status, tujuan, pengetahuan dan pengalaman, peran, sikap dan kebutuhan (Buchem et al., 2018).

Designate Persona Types, tahap ini dilakukakan pemilihan salah satu persona untuk persyaratan elisitasi. Berdasarkan uraian dari masing-masing jenis personas dan semua analisis yang dilakukan selama proses pembuatan personas, ditentukan orangnya. Diperlukan untuk menggunakan teknik orang lain untuk membantu developer untuk memahami kebutuhan dan karakteristik pengguna, sambil menghasilkan kemungkinan persyaratan aplikasi bahkan ketika pengguna tidak tersedia untuk validasi biasa selama pengembangan. Kemudian Build Use Cases dimulai dari actor (persona), stakeholder dan skenario.

Sistem dan lingkungan penggunaan yang dibutuhkan digambarkan dalam use case diagram. Deskripsi kebutuhan diambil dari kesimpulan deskripsi persona dari tahap sebelumnya. Implement and Evaluate Prototypes adalah tahap terakhir yaitu untuk merancang prototype dari semua hal di atas menggunakan Adobe XD. Mendeskripsikan kebutuhan dan solusi analisis dari use case kedalam desain. Dokumen ini juga berfungsi sebagai ruang lingkup dokumen kerja untuk pengembang. Dirancang dengan antarmuka yang mudah dipahami dan mudah digunakan dan memiliki potensi untuk pengembangan.

\section{TINJAUAN PUSTAKA}

Beberapa teknik untuk menggambarkan kepribadian persona telah diusulkan untuk melibatkan persona dalam proses pengembangan perangkat lunak dan menghasilkan suatu kebutuhan untuk aplikasi. Diantaranya sebagai berikut:

Metode yang digunakan Farshid (Anvari et al., 2015) yaitu studi secara empiris menggali variasi desain konseptual dari kepribadian persona. Hasil dari studi mengindikasikan bahwa persepsi partisipan, prioritas kebutuhan, dan kebutuhan sistem dapat dipengaruhi dari karakter kepribadian personality dari personas.
Kemudian Aoyama (Muniraj and Jagannatha, 2007) mengemukakan metode Persona-ScenarioGoal (PSG) digunakan untuk mengidentifikasi serangkaian kebutuhan nilai dari beberapa dan bahkan kebutuhan yang saling bertentangan oleh menggabungkan persona, skenario dan berorientasi pada tujuan teknik. Hasil dari penelitian ini, metodologi PSG menyediakan secara efektif sistematis prosedur untuk mengidentifikasi kebutuhan yang dimaksudkan memenuhi serangkaian tujuan dalam aplikasi pengguna masal.

Idoughi dkk. dalam penelitiannya (Idoughi, Seffah and Kolski, 2012) menggunakan metode dimana unsur-unsur deskripsi persona membantu merancang antarmuka aplikasi sementara fungsi yang diidentifikasi diekstraksi. Hasil penelitian ini adalah untuk mengintegrasikan masalah HCI (dan terutama metode desain terkait desain interaksi seperti, desain pengalaman pengguna dan desain berbasis skenario) kedalam desain layanan didefinisikan dalam bidang ilmu layanan yang muncul dan manajemen.

Menggunakan metode berdasarkan versi Cooper yang ditulis oleh Silvia (Acuña, Castro and Juristo, 2012) langkah-langkah baru untuk menyesuaikan personas dengan proses pengembangan perangkat lunak telah dimasukkan dalam teknik ini. Use case dibangun dalam salah satu tahap, didasarkan pada personas yang dihasilkan dan memperoleh pengetahuan tentang pengguna dengan proses menciptakan personas. Hasil yang diperoleh adalah untuk mendapatkan pemahaman yang lebih dalam tentang pengguna yang berinteraksi dengan sistem dan memberikan dukungan untuk mengembangkan sistem yang sesuai dengan karakteristik pengguna.

Sedangkan Sim (Sim and Brouse, 2014) menggunakan Concept Development Process (CDP) untuk meningkatkan proses rekayasa kebutuhan dengan memasukkan konsep persona ke dalam kegiatan rekayasa kebutuhan untuk memungkinkan engineers, analysis, dan developers mendapatkan pemahaman yang lebih baik tentang kebutuhan pengguna dan perilaku di awal proses rekayasa kebutuhan. Hasil dari penelitian ini, memberikan kontribusi menuju mengintegrasikan konsep persona ke dalam kegiatan rekayasa kebutuhan dan menyelidiki hubungan konsep sudut pandang, skenario, tugas, tujuan, dan kebutuhan.

Tabel 1. Perbandingan Teknik Penelitian Terdahulu

Farshid Mikio Djilali Silvia T. Sim and Anvari Aoyama Idoughi Acuña Brouse

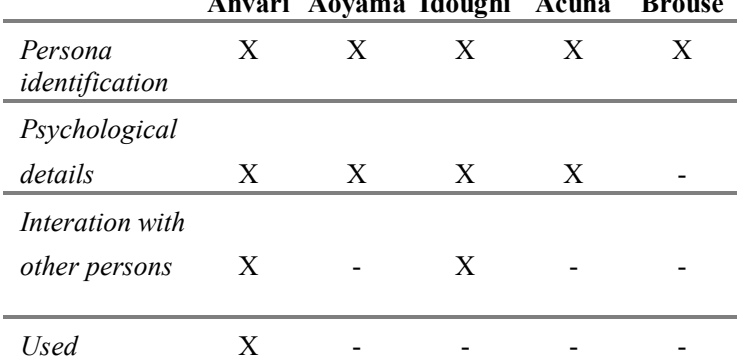




\begin{tabular}{lccccc} 
& $\begin{array}{c}\text { Farshid } \\
\text { Anvari }\end{array}$ & $\begin{array}{c}\text { Mikio } \\
\text { Aoyama }\end{array}$ & $\begin{array}{c}\text { Djilali } \\
\text { Idoughi }\end{array}$ & $\begin{array}{c}\text { Silvia T. Sim and } \\
\text { Acuña }\end{array}$ & \begin{tabular}{l} 
Brouse \\
\hline $\begin{array}{l}\text { applications / } \\
\text { services }\end{array}$
\end{tabular} \\
\hline $\begin{array}{l}\text { Skills / } \\
\text { previous } \\
\text { experiences }\end{array}$ & $\mathrm{X}$ & $\mathrm{X}$ & $\mathrm{X}$ & $\mathrm{X}$ & $\mathrm{X}$ \\
\hline $\begin{array}{l}\text { Special needs / } \\
\text { accessibility }\end{array}$ & $\mathrm{X}$ & - & $\mathrm{X}$ & $\mathrm{X}$ & - \\
\hline
\end{tabular}

\section{PEMBAHASAN HASIL}

Penelitian ini mengambil studi kasus mengenai keabsahan data Presensi di kelas perkuliahan serta hubungannya dengan kemampuan kompetensi bagi mahasiswa. Permasalahan ini akan melibatkan mahasiswa yang sedang aktif menempuh perkuliahan. Data Presensi dalam setiap mata kuliah masih tidak bisa sepenuhnya dianggap valid, dikarenakan sebagian mahasiswa masih melakukan tindakan titip absen kepada temannya. Di samping itu, tindakan tersebut dianggap tidak benar karena tidak hadirnnya mahasiswa di dalam kelas dapat memengaruhi kemampuan kompetensi mahasiswa. Namun dalam beberapa kasus, kemampuan kompetensi mahasiswa di kelas juga tidak bisa selamanya diukur pada aktif atau tidaknya mahasiswa tersebut hadir di dalam kelas. Sehingga hasil yang akan dicapai dalam penelitian ini adalah memaksimalkan tingkat validasi data Presensi kelas. Berikut penjabaran dari teknik persona yang digunakan dalam penyelesaian masalah:

\section{Activity 1: Hypotesis}

Dalam studi ini ditentukan bahwa terdapat 2 persona, yaitu mahasiswa dan dosen. Dengan masing-masing hipotesis yang menggambarkan masalah pada setiap persona terdapat pada Tabel 2 .

\begin{tabular}{ccccc}
\multicolumn{6}{c}{ Tabel 2. Hipotesis } \\
\hline Activities & Persona & \multicolumn{3}{c}{ Explanation } \\
\hline H0 & Mahasiswa & $\begin{array}{l}\text { Mahasiswa yang jarang masuk } \\
\text { mengakibatkan tidak } \\
\text { kuliah tertentu }\end{array}$ \\
\hline H1 & Dosen & $\begin{array}{l}\text { Tidak semua dosen } \\
\text { mengelola Presensi di kelas (memberikan }\end{array}$ \\
& & Presensi langsung kepada mahasiswa). \\
\hline
\end{tabular}

\section{Activity 2: Ranges of Behavioural Variables}

Dibuat beberapa variabel seperti yang terlihat pada tabel, yang mana variabel ini akan menampung nilai dari responden. Dengan cara wawancara, diajukan pertanyaan-pertanyaan ini kepada responden dan responden menjawab berdasarkan batasan-batasan jawaban yang telah disediakan demi memudahkan pemetaan respon.

Sebelumnya pada hipotesis, disebutkan bahwa ada 2 persona yakni mahasiswa dan dosen. Oleh karena itu, akan ada Behavioral Variable yang berbeda antar persona, untuk mahasiswa dijabarkan pada Tabel 3 sedangkan dosen pada Tabel 4.

Tabel 3. Behavioral Variable Mahasiswa

\begin{tabular}{ll}
\hline No Observed Behavioural Variabel & Scale \\
\hline 1. Seberapa sering TA (Titip Absen) & Sering - Tidak pernah \\
\hline 2. Pemahaman Materi & Paham - Tidak paham \\
\hline 3. Frekuensi tidak hadir dalam kelas & Sering - Tidak pernah \\
\hline 4. Motivasi masuk kelas & Presensi - Ingin belajar \\
\hline
\end{tabular}

Tabel 4. Behavioral Variable Dosen

\begin{tabular}{lc}
\hline No Observed Behavioural Variabel & Scale \\
\hline $\begin{array}{l}\text { 1. Memanggil mahasiswa atau } \\
\text { memberikan Presensi kepada } \\
\text { mahasiswa }\end{array}$ & Memanggil - Memberikan \\
\hline \begin{tabular}{l} 
2. Tujuan dari tindakan tersebut \\
\multicolumn{2}{l}{ Toleransi ketidakhadiran dalam } \\
kelas
\end{tabular} & $\begin{array}{c}\text { Ingin mengenal - } \\
\text { Membuang wkatu }\end{array}$ \\
\hline
\end{tabular}

\section{Activity 3: Mapping of Interview Subject (Emotion Card)}

Pada tahap ini, dilakukan pemetaan jawaban responden mahasiswa dan dosen dalam emoticon card, dengan menggambarkan pertanyaan serta range jawaban. Responden yang terlibat dalam tahap ini adalah sebanyak 5 orang mahasiswa dan 3 dosen dengan masing-masing responden atau subjek diberi warna yang berbeda untuk membedakan. Wawancara dengan responden dan setelah mendapatkan jawaban dari mereka, lalu memetakannya ke dalam emoticon card seperti yang terlihat pada Gambar 1 untuk pemetaan jawaban mahasiswa dan Gambar 2 untuk pemetaan jawaban dosen.

\section{Activity 4: Significant Behaviour}

Setelah memetakan jawaban responden dalam emoticon card, dibuat sebuah kesimpulan dari pola yang terbentuk dalam pemetaan jawaban sebelumnya. Seperti yang terlihat pada Gambar 3, dapat diambil kesimpulan bahwa mahasiswa yang sering titip absen tidak memahami materi. Begitu pula pada pemetaan jawaban dosen pada Gambar 4, jawaban signifikan yang didapat menyimpulkan adanya keinginan dosen untuk mengenal setiap mahasiswa melalui metode Presensi manual dengan memanggil mahasiswa satu persatu.

\section{Activity 5: Synthesize}

Hasil aktifitas ini adalah merangkum dan melakukan sistesis terhadap jawaban seluruh responden yang telah didapat. Berdasarkan perhitungan yang dihasilkan dari meta-analisis oleh penelitian milik Jacob Nielsen. Kelima responden mahasiswa telah menghasilkan $85 \%$ probabilitas penyelesaian masalah yang telah terjadi dengan interval pengumpulan informasi yang signifikan naik dengan hanya lima responden. 


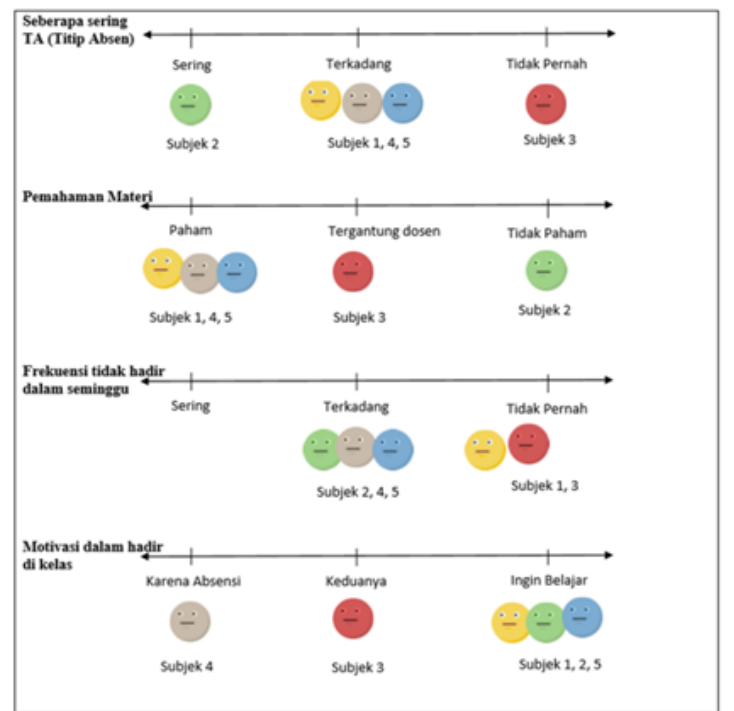

Gambar 1. Emoticon Card Mahasiswa

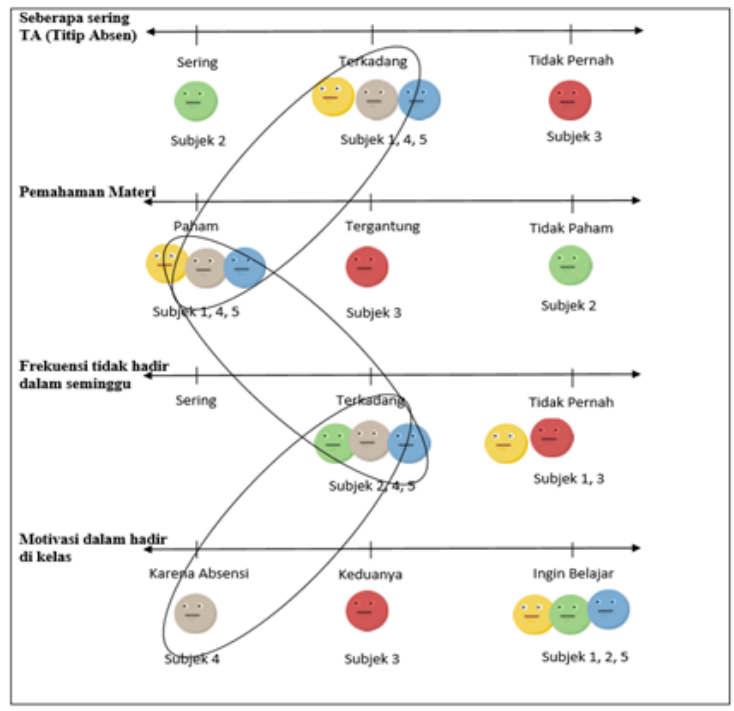

Gambar 3. Significant Behavior Mahasiswa

Activity 6: Check for Redundancy and Completeness

Pada tahap ini, dilakukan proses validasi dari semua informasi yang telah dikumpulkan dan diolah pada tahap-tahap aktifitas sebelumya. Menggunakan tahapan validasi 4 (empat) fase, yakni terlebih dahulu dilakukan pengecekan terhadap jawaban responden dengan memastikan seluruh responden telah memberikan jawaban dan informasi yang dibutuhkan sebagai fase pertama. Kemudian dilakukan validasi fase kedua dengan melibatkan responden lain dalam kategori. Dilanjutkan dengan fase ketiga yakni memeriksa variabel apakah variabel yang ada dapat memenuhi untuk penggalian informasi tentang masalah yang ada, hasilnya adalah semua variabel yang dibutuhkan telah lengkap pada tahap sebelumnya. Dan fase terakhir adalah analisa atas anomali yang terdapat pada jawaban para responden.
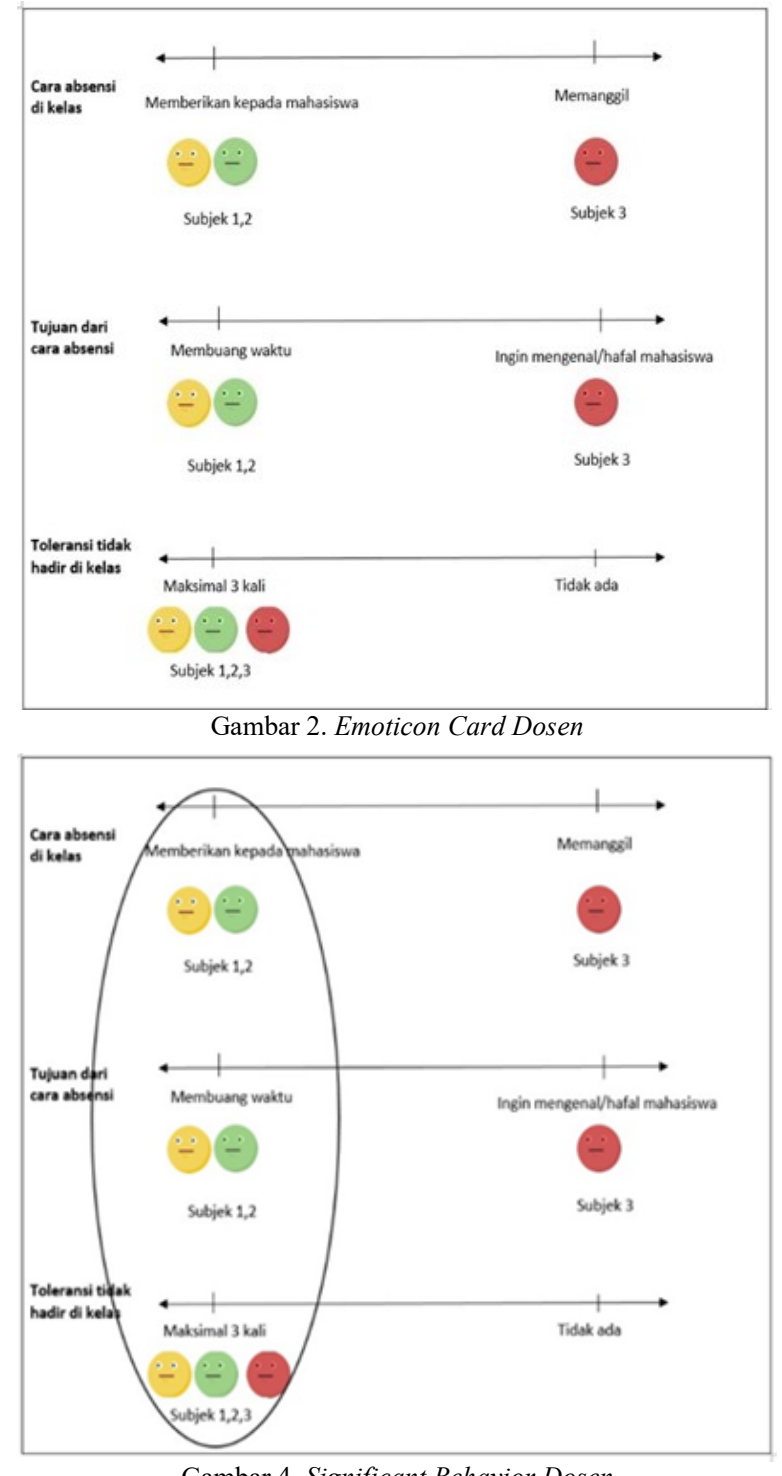

Gambar 4. Significant Behavior Dosen

Activity 7 : Expand the Description of Attributes and Behaviours

Pada aktifitas ini, dikumpulkan berupa data diri yang secara rinci juga informasi yang menggambarkan kepribadian beserta kegiatan sehari-hari oleh responden berkaitan dengan kehidupan dalam wilayah perkuliahan.Informasi tentang responden yang ada hubungannya dengan pengunaan perangkat lunak dapat membantu dalam pengembangan sistem. Persona yang didapatkan kemudian akan dirangkum informasinya dalam Persona Foundation Document pada Gambar 5.

\section{Activity 8 : Designate Persona Types}

Tahap ini akan menjabarkan seluruh informasi dari persona terpilih secara rinci dan menjadikannya sebagai persona primer. Deskripsi informasi ditulis dan disajikan dengan semenarik mungkin dalam Gambar 6 untuk menampilkan data tentang persona mulai dari kebiasaan, kemampuan, hingga deskripsi diri secara psikologi dalam kehidupan perkuliahan. 


\section{Activity 9 : Build Use Cases}

Pada Gambar 7, terdapat diagram use case yang menjelaskan keterhubungan antara mahasiswa dan dosen di Presensi Online ini. Dan pada Tabel 5 akan dijelaskan lebih detail dari setiap use case dalam Use Case Description.

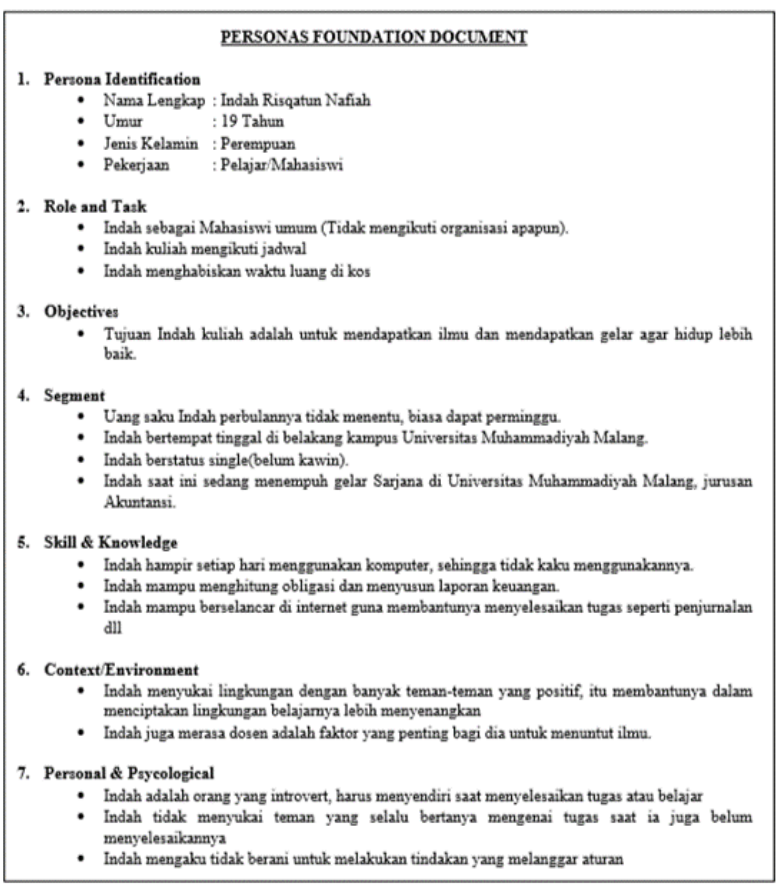

\section{Activity 10 : Implement and Evaluate Prototypes}

Seluruh hasil pengumpulan informasi dan desain berupa dokumen deskripsi persona serta use case kemudian dilanjutkan dengan desain antarmuka serta protoype dari sistem Presensi online pada Gambar 8 dan Gambar 9.
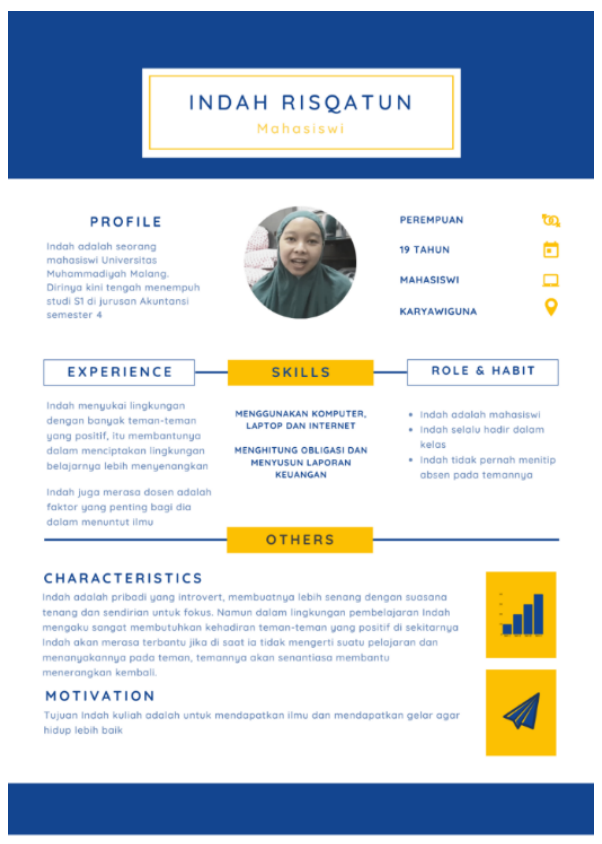

Gambar 6. Primary Persona Description

Gambar 5. Persona Foundation Document

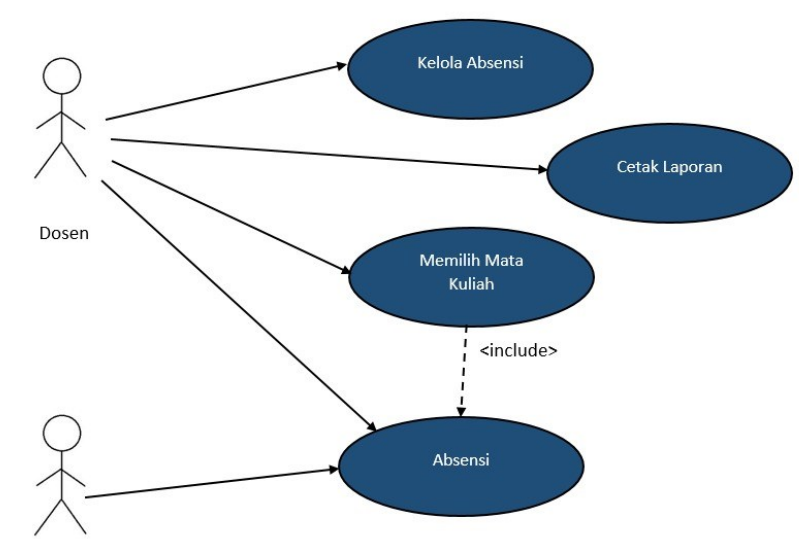

Mahasiswa

Gambar 7. Use Case Diagram

Tabel 5. Use Case Description

\begin{tabular}{ll}
\hline \multicolumn{1}{c}{ Actor } & Description \\
\hline Dosen & Setelah dosen login ke sistem, dosen akan memilih mata kuliah yang ia ajar, lalu membiarkan \\
& mahasiswa untuk men-scan KTM sebelum pelajaran dimulai(masuk) dan ketika selesai(pulang). \\
& Dosen mampu menginputkan keterangan tertentu bagi mahasiswanya yang sakit/ijin(edit). Dan \\
& ketika ingin mencetak laporan, bisa menggunakan fitur cetak laporan. \\
\hline Mahasiswa & Mahasiswa wajib membawa KTM, dan men-scannya di meja dosen sebelum dan sesudah pelajaran. \\
\hline
\end{tabular}




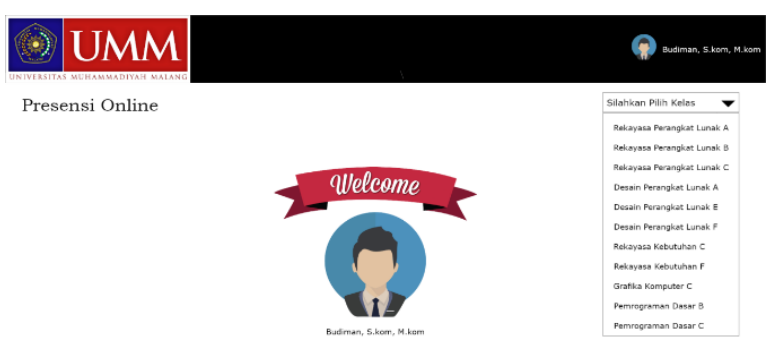

Gambar 8. Desain Prototype Sistem

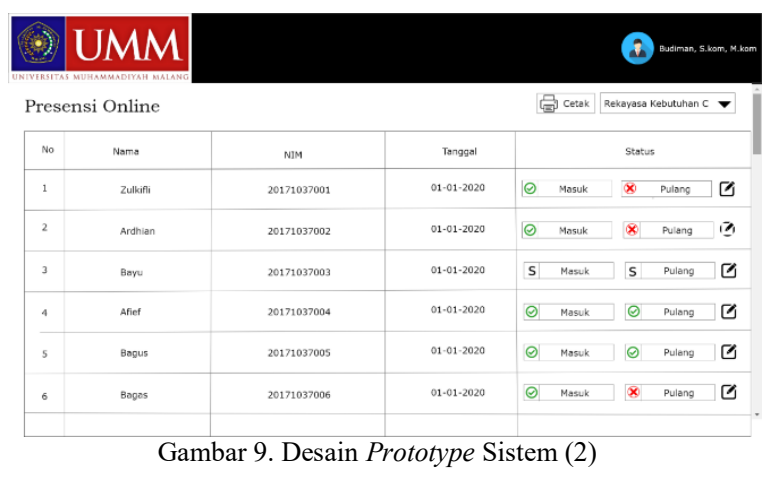

\section{KESIMPULAN}

Permasalahan didalam pengembangan perangkat lunak menjadi sangat krusial ketika setiap fase harus dijalankan secara tepat. Dari setiap fase tersebut, proses elisitasi yang merupakan fase awal dari pengembangan menjadi sangat penting. Beberapa permasalahan yang terjadi didalam fase tersebut dikarenakan pengembang tidak dapat mengidentifikasi secara detail kebutuhan dari pengguna, kebutuhan seharusnya menjadi solusi dari permasalahan yang dialami. Dalam penelitian yang dilakukan digunakan pendekatan yang sering digunakan didalam pengembangan HCI yakni teknik user persona, dimana dari hasil penelitian didapatkan bahwa perlu dilakukan lebih dari beberapa kali iterasi untuk mendapatkan pendekatan yang sesuai dengan kebutuhan pengguna.

\section{DAFTAR PUSTAKA}

ACUÑA, S.T., CASTRO, J.W. AND JURISTO, N., 2012. A HCI technique for improving requirements elicitation. In: Information and Software Technology. pp.1357-1375.

ANVARI, F., RICHARDS, D., HITCHENS, M. AND BABAR, M.A., 2015. Effectiveness of Persona with Personality Traits on Conceptual Design. In: Proceedings International Conference on Software Engineering. pp.263-272.

BAGRIYANIK, S. AND KARAHOCA, D., 2014. System analyst expectations from requirements engineering tools: A human computer interaction perspective. Global Journal of Computer Sciences, 04(1), pp.7-16.
BLANCO,T., LOPEZ-FORNIES, I. AND

ZARAZAGA-SORIA, F.J., 2017.

Deconstructing the Tower of Babel: a design method to improve empathy and teamwork competences of informatics students. International Journal of Technology and Design Education, 27(2), pp.307-328.

BUCHEM, I., KONERT, J., CARLINO, C., CASANOVA, G., RAJAGOPAL, K., FIRSSOVA, O. AND ANDONE, D., 2018. Designing a Collaborative Learning Hub for Virtual Mobility Skills. Learning and Collaboration Technologies. Design, Development and Technological Innovation,

CASTRO, J.W., ACUÑA, S.T. and JURISTO, N., 2008. Enriching requirements analysis with the personas technique. In: CEUR Workshop Proceedings.

ESTUBLIER, J., 2000. Software configuration management: A roadmap. In: Proceedings of the Conference on the Future of Software Engineering, ICSE 2000. pp.279-289.

FERREIRA, B., SILVA, W., BARBOSA, S.D.J. AND CONTE, T., 2018. Technique for representing requirements using personas: A controlled experiment. IET Software, 12(3), pp.280-290.

IDOUGHI, D., SEFFAH, A. AND KOLSKI, C., 2012. Adding user experience into the interactive service design loop: A personabased approach. Behaviour and Information Technology, 31(3), pp.287-303.

MULLA, N., 2012. A New Approach to Requirement

Elicitation Based on Stakeholder Recommendation and Collaborative Filtering. International Journal of Software Engineering \& Applications, 3(3), pp.5160.

MUNIRAJ, G. AND JAGANNATHA, V., 2007. Requirements engineering using prototyping projects in healthcare diagnostic software applications. In: Proceedings - 15th IEEE International Requirements Engineering Conference, RE 2007. pp.307-312.

SANTOS, M., RABELO, J., BARRETO, R. AND CONTE, T., 2014. Persona security: A technique for supporting the elicitation of security requirements. In: Proceedings of the International Conference on Software Engineering and Knowledge Engineering, SEKE. pp.603-608.

SIM, W.W. and BROUSE, P.S., 2014. Empowering requirements engineering activities with personas. In: Procedia Computer Science. pp.237-246.

WONG, L.R., MAURICIO, D. AND RODRIGUEZ, 
252 Jurnal Teknologi Informasi dan Ilmu Komputer (JTIIK), Vol. 8, No. 2, April 2021, hlm. 245-252

G.D., 2017. A systematic literature review about software requirements elicitation. Journal of Engineering Science and Technology, . 